Volume : 04
Nomor : 03
Bulan : September
Tahun : 2018
http://ejurnal.pps.ung.ac.id/index.php/AKSARA/index

\title{
Meningkatkan Kemandirian Dalam Aktivitas Belajar Melalui Layanan Informasi Pada Siswa Di SMP Negeri 1 Ponelo Kepulauan
}

\author{
Imran Atute \\ Dinas Pendidikan dan Kebudayaan \\ Kabupaten Gorontalo Utara
}

Received: 12 Januari 2018; Revised: 26 Februari 2018; Accepted: 28 Juli 2018

DOI: http://dx.doi.org/10.37905/aksara.4.3.283-292.2018

\begin{abstract}
ABSTRAK
Hasil temuan pada penelitian ini dapat disimpulkan yaitu layanan informasi dapat meningkatkan jumlah siswa yang mandiri adalam aktivitas belajar yaitu 4 orang atau $24 \%$ pada siklus I, meningkat menjadi 14 orang atau $82 \%$ pada siklus II. Hasil ini menunjukkan telah memenuhi indikator kinerja dan hipotesis tindakan yang berbunyi :'jika digunakan layanan informasimaka kemandirian belajar padasiswa kelas IX di SMP Negeri 1 Ponelo Kepulauan kabupaten Gorontalo utara dapat ditingkatkan.Implikasi dari hasil temuan ini menunjukkan bahwa makna kemandirian yang meliputi perilaku mampu berinisiatif, mampu mengatasi hambatan/masalah, mempunyai rasa percaya diri dan dapat melakukan sesuatu sendiri tanpa bantuan orang lain dapat diatasi dalam kegiatan pembelajaran sekolah dasar melalui penggunaan layanan informasi. Dengan demikian kemandirian sebagai hasrat untuk mengerjakan segala sesuatu bagi diri sendiri atau suatu keadaan dimana seseorang yang memiliki hasrat bersaing untuk maju demi kebaikan dirinya akan mampu mengambil keputusan dan inisiatif untuk mengatasi masalah yang dihadapi, memiliki kepercayaan diri dalam mengerjakan tugas-tugasnya, bertanggungjawab tetrhadap apa yang dilakukannya.
\end{abstract}

Kata Kunci: Kemandirian, Belajar dan Layanan Informasi

\section{PENDAHULUAN}

Setiap siswa memiliki cara tersendiri dalam menginterpretasikan dan beradaptasi dengan lingkungannya. Hal ini karena setiap siswa memiliki struktur kognitif yang ada dalam pikiran sebagai hasil pemahaman terhadap objek yang ada dalam lingkungannya. Pemahaman siswa tentang objek tersebut berlangsung melalui proses asimilasi (menghubungkan objek dengan konsep yang sudah ada dalam pikiran) dan proses akomodasi (proses memanfaatkan konsep-konsep dalam pikiran untuk menafsirkan objek). Proses tersebut jika berlangsung terus-menerus akan membuat pengetahuan lama dan pengetahuan baru menjadi seimbang. Dengan cara seperti itu secara bertahap siswa dapat membangun kemandirian dalam belajar melalui interaksi dengan lingkungannya. Kemandirian siswa dalam aktivitas belajar bertujuan agar siswa mengetahui secara sadar apa yang dilakukannya dan tahu apa yang menjadi tujuannya. Siswa akan merasa bahagia bahwa ia mempunyai arti bagi diri dan orang 


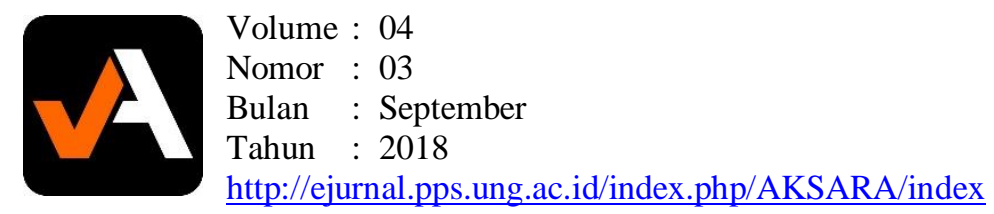

lain, ia mampu mengenali diri, mengetahui kekurangan dan kelebihan, dapat menerima diri dan orang lain seperti apa adanya, dapat bertanggung jawab atas apa yang dilakukannya, pantang mundur meski ada kekurangan pada dirinya dan juga berani menghadapi kenyataan yang ada. Namun pada kenyataannya siswadi kelas IX di SMP Negeri 1 Ponelo Kepulauan Kabupaten Gorontalo Utara bahwa dari sampel 17 orang siswa hanya 4 orang yang sering mandiri dalam aktivitas belajar sedangkan 13 orang siswa cenderung belum dapat mandiri adalam aktivitas belajar. Kondisi ini tercemin dari adanya perilaku yang malas belajar. Mereka dalam menyelesaikan pekerjaan rumah hanya menyalin dari teman atau sama sekali tidak mengerjakannya., tidak berani untuk menunjukkan. Di samping itu kondisi lain yang menggambarkan siswa kurang memiliki kemandirian dalam belajar terlihat ketika dalam mengikuti proses belajar mengajar bersikap pasif, tidak berani bertanya apabila menghadapi kesulitan, dalam ulngan mempunyai kesukaan untuk mencontek pekerjaan teman atau mencontek dari lembaran-lembaran yang telah dipersiapkan dari rumah.

Menurut Mutadin (2002: 1) bahwa kemandirian adalah suatu sikap individu yang diperoleh secara kumulatif selama perkembangan, dimana individu akan terus belajar untuk bersikap mandiri dalam menghadapi berbagai situasi lingkungan, sehingga individu pada akhirnya akan mampu berfikir dan bertindak sendiri dengan kemandiriannya. Kemandirian pada iswa berawal dari keluarga dan dipengaruhi oleh pola pembelajaran yang dilakukan oleh guru yang berperan dalam membimbing, membantu dan mengarahkan siswa untuk menjadi mandiri. Untuk mengatasi masalah tersebut sebenarnya telah ada upaya dari guru seperti dengan memberikan layanan belajar kelompok di sekolah tetapi hasilnya belum efektif dan perilaku siswa dalam aktivitas belum mencerminkan kemandirian. Oleh sebab itu dalam penelitian ini penulis berupaya untuk memecahkannya melalui layanan informasi. Karena layanan informasi memberikan kesempatan untuk menjadi instrumen bagi perkembangan pribadi orang lain, adanya kesempatan untuk berinteraksi, berkomunikasi, yang akan menimbulkan adanya pemahaman dan perkembangan diri.

\section{KAJIAN PUSTAKA Kemandirian}

Kemandirian merupakan salah satu aspek kepribadian yang sangat penting bagi individu. Individu dalam menjalani kehidupan tidak akan lepas dari cobaan dan tantangan. Kemudian Brewer (2010:1) bahwa individu yang memiliki kemandirian yang tinggi relatif mampu menghadapi segala permasalahan, karena individu yang mandiri tidak tergantung pada orang lain, selalu berusaha menghadapi dan memecahkan masalahnya. Kemandirian berasal dari kata mandiri yang berarti berdiri sendiri. Dari makna ini, mandiri mempunyai pengertian tidak tergantung pada orang lain, serta melakukan aktivitas, inisiatif, dan kreatifitasnya sendiri. Sikap kemandirian sebagai suatu keadaan personalitik yang bercirikan adanya kecenderungan determinasi diri dalam kerangka dukungan sosial atau inner person with inner activities.

Definisi ini mempunyai pengertian bahwa sikap kemandirian seseorang merupakan kepribadian yang dimiliki oleh orang yang bersangkutan dalam dimensi 


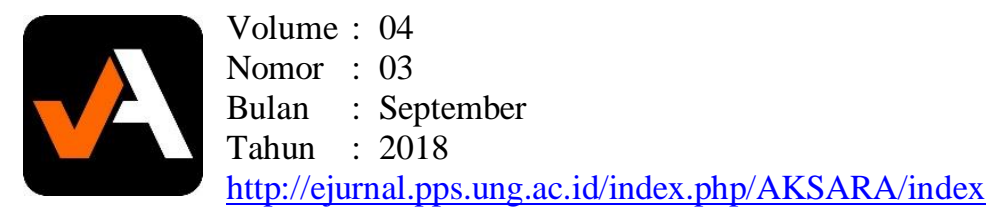

sosial. Secara singkat definisi ini mempunyai pengertian bahwa individu mandiri adalah individu yang mampu menentukan diri, arah dan tindakannya dalam kerangka hubungan sosial. Seperti halnya salah satu teori psikologi mengenai masalah kemandirian, yaitu Secara psikologis manusia digerakkan oleh sejumlah kebutuhan yang berlainan, yaitu kebutuhan untuk mandiri dan kebutuhan untuk bergantung. Kebutuhan mandiri meliputi semua tindakan yang diambil untuk berpikir secara bebas, merasa bebas mengerjakan sesuatu tanpa memikirkan orang lain. Menurut (dalam Sahama, 2010:1) bahwa seseorang yang mandiri adalah seseorang yang mampu mengekspresikan dirinya secara bebas tanpa adanya kontrol dari luar. Kemandirian adalah mampu mengatur diri sendiri sesuai dengan hak dan kewajibannya, mampu menentukan nasibnya sendiri, tidak tergantung orang lain sampai batas kemampuannya, mampu bertanggung jawab atas keputusan, tindakan, dan perasaannya sendiri serta mampu membuang pola perilaku yang mengingkari kenyataan.

Berdasarkan berbagai pengertian di atas, dapat diambil kesimpulan bahwa kemandirian adalah suatu sikap pada diri seseorang yang ditunjukkan dengan kemampuannya dalam menentukan diri, arah dan tindakannya dalam kerangka hubungan sosial, bebas dan original tanpa adanya pengaruh dari luar, mampu mengambil inisiatif, mengatasi hambatan, tidak tergantung pada orang lain sehingga ia dapat mengaktualisasikan dirinya serta merealisasikan harapan-harapannya. Schaeffer (2010:1) mengatakan bahwa tingkat kemandirian yang ada pada setiap orang berbedabeda, ada yang tinggi dan ada yang rendah, "kemandirian yang tinggi cenderung memiliki rasa percaya diri tinggi, banyak inisiatif, rasa tanggung jawab, serta mengerjakan sesuatu untuk dan oleh dirinya sendiri" Gie (2010:1) mengatakan bahwa kemandirian belajar jika dihubungkan dengan belajar, kemandirian merupakan salah satu faktor internal yang memberikan kontribusi dalam pencapaian prestasi. Kemandirian siswa dalam belajar adalah situasi yang memungkinkan seseorang siswa memperoleh pengetahuan dan pemahaman serta keterampilan atas prakarsa atau inisiatif dan kemampuan sendiri.

\section{Layanan Informasi}

Menurut Priyatno dan Erman (1999: 259) bahwa layanan informasi bermaksud memberikan pemahaman kepada individu-individu yang berkepentingan tentang berbagai hal yang diperlukan untuk suatu tugas atau kegiatan atau menentukan arah suatu tujuan atau rencana yang dikehendaki. Pendapat ini menunjukkan bahwa layanan informasi merupakan suatu layanan yang berupaya memenuhi kekurangan individu akan informasi yang mereka perlukan. Layanan informasi juga bermakna usaha-usaha untuk membekali siswa dengan pengetahuan serta pemahaman tentang linkungan hidupnya dan tentang proses perkembangan siswa. Kemudian menurut Dewa dan Desak (2002: 57) bahwa layanan informasi, yaitu pelayanan bimbingan dan konseling yang memungkinkan konseling memahami lingkungan (seperti sekolah) yang baru dimasuki konseling, untuk mempermudah dan memperlancar berperannya konseli di lingkungan yang baru. Tujuan pelayanan informasi ditujukan untuk siswa baru dan untuk pihak-pihak lain (terutama orang tua siswa) guns memberikan pemahaman dan 


Volume : 04
Nomor : 03
Bulan : September
Tahun : 2018
http://ejurnal.pps.ung.ac.id/index.php/AKSARA/index

penyesuaian diri (terutama penyesuaian siswa ) terhadap lingkungan sekolah yang baru dimasuki. Hasil yang diharapkan dari layanan informasi ialah dipermudahnya penyesuaian diri siswa terhadap pola kehidupan sosial, kegiatan belajar, dan kegiatan lain yang mendukung keberhasilan siswa. Demikian juga orang tua siswa, dengan memahami kondisi, situasi, dan tuntutan sekolah Siswa nya akan dapat memberikan dukungan yang diperlukan bagi keberhasilan belajar nya. Dalam menjalani kehidupan dan perkembangan dirinya, individu memerlukan berbagai informasi baik untuk keperluan kehidupannya sehari-hari, sekarang, maupun untuk perencanaan kehidupannya ke dapan. Individu bisa mengalami masalah dalam kehidupannya seharihari maupun dalam memenuhi kebutuhannya di masa depan, akibat tidak menguasai dan tidak mampu mengakses informasi. Melalui layanan informasi individu dibantu untuk mengakses informasi.

\section{METODE PENELITIAN}

Penelitian ini dilakukan pada siswa kelas IX di SMP Negeri 1 Ponelo Kepulauan Kabupaten Gorontalo Utara, provinsi Gorontalo sebagai sampel yang berjumlah 17 orang terdiri dari 10 orang perempuan dan 7 orang laki-laki. Teknik yang

digunakan untuk mengumpulkan dalam penelitian ini adalah observasi. Sasaran yang diobservasi adalah kemampuan guru dalam menerapkan layanan informasi dengan kemandirian dalam aktivitas belajar. Data yang diharapkan dalam penelitian ini adalah kemampuan guru dalam menerapkan layanan informasi dan kermandirian siswa dalam aktivitas belajar. Sumber data dalam penelitian ini adalah siswa kelas IX di SMP Negeri 1 Ponelokepulauan Kabupaten Gorontalo yang berjumlah 17 orang siswa dan guru sebagai pelaksana penelitian. Data tersebut diperoleh melalui kegiatan observasi oleh mitra pada setiap siklus pembelajaran.Data dalam penelitian ini dianalisis secara deskriptif yaitu mendeskripsikan atau menggambarkan data hasil pengamatan sesuai apa adanya baik secara kualitatif maupun secara kuantitatif.

\section{HASIL PENELITIAN DAN PEMBAHASAN Hasil Penelitian}

Penelitian ini dilakukan pada siswa kelas IX di SMP Negeri 1 Ponelokepulauan Kabupaten Gorontalo Utara sebagaisampel yang berjumlah 17 orang. Langkah awal yang dilakukan dalam melaksanakan kegiatan penelitian ini adalah melakukan observasi terhadap kelas yang digunakan sebagai subyek dalam penelitian, kemudian dilanjutkan dengan penyusunan rencana pembelajaran. Untuk menghasilkan data yang akurat, peneliti didamping oleh seorang Ipartisipan atau guru pengamat, yang melakukan observasi terhadap seluruh aktivitas perlakuan baik mengenai kemampuan guru dalam menerapkan layanan informasipada pembelajaran di kelas. Untuk menjaring data dalam penelitian ini digunakan observasi langsung oleh guru mitra. Instrumen yang digunakan untuk mengukur kemampuan guru dalam menerapkan layanan informasi berupa observasi yang terdiri 4 (empat) indikator. Kemudian untuk menjaring data mengenai kemandirian siswa dalam aktivitas belajar menggunakan 


Volume : 04
Nomor : 03
Bulan : September
Tahun : 2018
http://ejurnal.pps.ung.ac.id/index.php/AKSARA/index

observasi yang terdiri dari tiga indikator yaitu menerima tugas yang diberikan guru, mempertanggungjawabkan hasil kerja dan berinisiatif sendiri.

Tabel 1. Hasil Observasi Awal Kemandirian dalam Aktivitas Belajar

\begin{tabular}{|c|l|c|c|}
\hline \multirow{2}{*}{ No } & \multirow{2}{*}{ Kualitaskemandirian } & \multicolumn{2}{|c|}{ Siswa } \\
\cline { 3 - 4 } & & Jumlah & Persentase \\
\hline 1 & Mandiri & 4 & 24 \\
\hline 2 & cukupmandiri & 2 & 12 \\
\hline 3 & kurangmandiri & 3 & 46 \\
\hline 4 & tidakmandiri & 17 & 100 \\
\hline & Jumlah & \multicolumn{2}{c}{} \\
\hline
\end{tabular}

Data pada tabel di atas menunjukkan bahwa pada kegiatan observasi awal jumlah siswa yang tidak mandiri dalam aktivitas belajar sebanyak 4 orang atau $24 \%$, kurang mandiri dalam aktivitas belajar sebanyak 2 orang atau $12 \%$, jumlah Siswa yang cukup mandiri dalam aktivitas belajar sebanyak 3 orang atau $18 \%$ dan jumlah siswa yang mandiri dalam belajar hanya 8 orang atau $46 \%$. Paparan data di atas menunjukkan bahwa secara keseluruhan dominan aktivitas belajar siswa tidak mandiri. Dengan demikian peneliti harus melakukan tindakan agar siswa memiliki kemandirian dalam aktivitas belajar. Hasil pengolahan data pengamatan layanan informasi pada pertemuan pertama siklus I dipaparkan pada tabel berikut.

Tabel 2. Hasil pengolahan data pengamatan layanan informasi pada pertemuan pertama siklus I

\begin{tabular}{|c|c|c|c|}
\hline \multirow{2}{*}{ No } & \multirow{2}{*}{ Urian kegiatan } & \multicolumn{2}{|c|}{ Kriteria Pengamatan } \\
\hline & & $\mathrm{Ya}$ & Tidak \\
\hline \multirow{4}{*}{1.} & Kegiatan Awal & & \\
\hline & Membangun keakraban & & $\sqrt{ }$ \\
\hline & Menjelaskan pengertian topik & $\sqrt{ }$ & \\
\hline & Menjelaskan tujuan yang dicapai & & $\sqrt{ }$ \\
\hline \multirow{3}{*}{2.} & Kegiatan Inti & & \\
\hline & Membahas pokok-pokok materi layanan informasi & $\sqrt{ }$ & \\
\hline & Tanya jawab tentang materi layanan informasi & & $\sqrt{ }$ \\
\hline \multirow[t]{4}{*}{3.} & Kegiatan Akhir & & \\
\hline & Menyimpulkan materi layanan & $\sqrt{ }$ & \\
\hline & Refleksi diri. & & $\sqrt{ }$ \\
\hline & Jumlah & 3 & 4 \\
\hline
\end{tabular}

Berdasarkan data pada tabel 2 diperoleh gambaran bahwa layanan untuk indikator kegiatan awal aspek membangun keakraban tidak nampak dalam layanan, menjelaskan pengertian topik nampak dalam kegiatan layanan dan menjelaskan tujuan yang dicapai tidak nampak dalam layanan. 


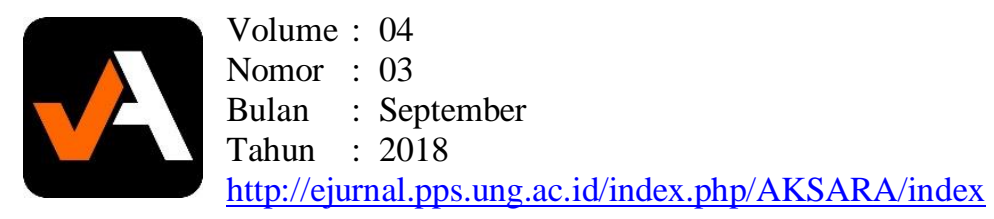

Hasil pengolahan data pengamatan layanan informasi pada pertemuan kedua siklus I dipaparkan pada tabel berikut.

Tabel 3. Hasil pengolahan data pengamatan layanan informasi

\begin{tabular}{|c|c|c|c|}
\hline \multirow{2}{*}{ No } & \multirow{2}{*}{ Urian kegiatan } & \multicolumn{2}{|c|}{ Kriteria Pengamatan } \\
\hline & & $\mathrm{Ya}$ & Tidak \\
\hline \multirow{4}{*}{1.} & Kegiatan Awal & & \\
\hline & Membangun keakraban & $\sqrt{ }$ & \\
\hline & Menjelaskan pengertian topik & $\sqrt{ }$ & \\
\hline & Menjelaskan tujuan yang dicapai & & $\sqrt{ }$ \\
\hline \multirow{3}{*}{2.} & Kegiatan Inti & & \\
\hline & Membahas pokok-pokok materi layanan informasi & $\sqrt{ }$ & \\
\hline & Tanya jawab tentang materi layanan informasi & & $\sqrt{ }$ \\
\hline \multirow[t]{4}{*}{3.} & Kegiatan Akhir & & \\
\hline & Menyimpulkan materi layanan & $\sqrt{ }$ & \\
\hline & Refleksi diri. & & $\sqrt{ }$ \\
\hline & Jumlah & 4 & 3 \\
\hline
\end{tabular}

Berdasarkan data pada tabel 3 diperoleh gambaran bahwa layanan untuk indikator kegiatan awal aspek membangun keakraban nampak dalam layanan, menjelaskan pengertian topik nampak dalam kegiatan layanan dan menjelaskan tujuan yang dicapai tidak nampak dalam layanan.

Hasil pengolahan data pengamatan layanan informasi pada pertemuan ketiga siklus II dipaparkan pada tabel berikut.

Tabel 7. Hasil Pengolahan Data Pengamatan Layanan Informasi pada Pertemuan Ketiga siklus II

\begin{tabular}{|c|c|c|c|}
\hline \multirow{2}{*}{ No } & \multirow{2}{*}{ Urian kegiatan } & \multicolumn{2}{|c|}{ Kriteria Pengamatan } \\
\hline & & $\mathrm{Ya}$ & Tidak \\
\hline \multirow{4}{*}{1.} & Kegiatan Awal & & \\
\hline & Membangun keakraban & $\sqrt{ }$ & \\
\hline & Menjelaskan pengertian topik & $\sqrt{ }$ & \\
\hline & Menjelaskan tujuan yang dicapai & $\sqrt{ }$ & \\
\hline \multirow{3}{*}{2.} & Kegiatan Inti & & \\
\hline & Membahas pokok-pokok materi layanan informasi & $\sqrt{ }$ & \\
\hline & Tanya jawab tentang materi layanan informasi & & $\sqrt{ }$ \\
\hline \multirow[t]{4}{*}{3.} & Kegiatan Akhir & & \\
\hline & Menyimpulkan materi layanan & $\sqrt{ }$ & \\
\hline & Refleksi diri. & & $\sqrt{ }$ \\
\hline & Jumlah & 5 & 2 \\
\hline
\end{tabular}

Berdasarkan data pada tabel 7 diperoleh gambaran bahwa layanan untuk indikator kegiatan awal aspek membangun keakraban nampak dalam layanan, 


Volume : 04
Nomor : 03
Bulan : September
Tahun : 2018
http://ejurnal.pps.ung.ac.id/index.php/AKSARA/index

menjelaskan pengertian topik nampak dalam kegiatan layanan dan menjelaskan tujuan yang dicapai nampak dalam layanan. Untuk indikator kegiatan diperoleh gambaran bahwa aspek membahas pokok-pokok materi layanan informasi nampak dalam kegiatan layanan dan aspek tanya jawab tentang materi layanan informasi belum nampak dalam layanan. Secara keseluruhan data hasil pengamayan layanan informasi pada pertemuan ketiga diperoleh gambaran terdapat lima aspek yang nampak dalam kegiatan layanan dan duat aspek yang nampak dalam kegiatan layanan.

Hasil pengolahan data pengamatan layanan informasi pada pertemuan keempat siklus II dipaparkan pada tabel berikut.

Tabel 8. Hasil pengolahan data pengamatan layanan informasi pada pertemuan Keempat siklus II

\begin{tabular}{|c|c|c|c|}
\hline \multirow{2}{*}{ No } & \multirow{2}{*}{ Urian kegiatan } & \multicolumn{2}{|c|}{ Kriteria Pengamatan } \\
\hline & & $\mathrm{Ya}$ & Tidak \\
\hline \multirow{4}{*}{1.} & Kegiatan Awal & & \\
\hline & Membangun keakraban & $\sqrt{ }$ & \\
\hline & Menjelaskan pengertian topik & $\sqrt{ }$ & \\
\hline & Menjelaskan tujuan yang dicapai & $\sqrt{ }$ & \\
\hline \multirow{3}{*}{2.} & Kegiatan Inti & & \\
\hline & Membahas pokok-pokok materi layanan informasi & $\sqrt{ }$ & \\
\hline & Tanya jawab tentang materi layanan informasi & $\sqrt{ }$ & \\
\hline \multirow[t]{4}{*}{3.} & Kegiatan Akhir & & \\
\hline & Menyimpulkan materi layanan & $\sqrt{ }$ & \\
\hline & Refleksi diri. & & $\sqrt{ }$ \\
\hline & Jumlah & 6 & 1 \\
\hline
\end{tabular}

Berdasarkan data pada tabel 8 diperoleh gambaran bahwa layanan untuk indikator kegiatan awal aspek membangun keakraban nampak dalam layanan, menjelaskan pengertian topik nampak dalam kegiatan layanan dan menjelaskan tujuan yang dicapai nampak dalam layanan. Untuk indikator kegiatan diperoleh gambaran bahwa aspek membahas pokok-pokok materi layanan informasi nampak dalam kegiatan layanan dan aspek tanya jawab tentang materi layanan informasi nampak dalam layanan.

\section{Pembahasan}

Tuntutan terhadap kemandirian ini sangat besar dan jika tidak direspon secara tepat bisa saja menimbulkan dampak yang tidak menguntungkan bagi perkembangan psikologis sang remaja di masa mendatang. Di tengah berbagai gejolak perubahan yang terjadi di masa kini, betapa banyak remaja yang mengalami kekecewaan dan rasa frustrasi mendalam terhadap orangtua karena tidak kunjung mendapatkan apa yang dinamakan kemandirian. Mencermati kenyataan tersebut, peran guru sangatlah besar dalam proses pembentukan kemandirian seorang. Guru diharapkan dapat memberikan kesempatan pada siswa agar dapat mengembangkan kemampuan yang dimilikinya, 
belajar mengambil inisiatif, mengambil keputusan mengenai apa yang ingin dilakukan dan belajar mempertanggungjawabkan segala perbuatannya. Dengan demikian siswa akan dapat mengalami perubahan dari keadaan yang sepenuhnya tergantung pada guru menjadi mandiri. Sehubungan dengan itu hasil penelitian ini menunjukkan bahwa terjadi peningkatan kemandirian belajar siswa setelah dilakukan tindakan layanan informasi. Pada siklus I hasil pengamatan layanan informasi terdapat tiga aspek yang nampak dan empat aspek yang belum nampak. Hasil ini dapat meningktakan kemandirian belajar siswa yaitu 4 orang atau $24 \%$ yang memiliki kualitas, jumlah siswa yang belajar cukup mandiri berjumlah 5 orang atau $29 \%$, dan jumlah siswa yang belajar kurang mandiri berjumlah 4 orang atau $24 \%$ dan jumlah siswa yang belajar tidak mandiri berjumlah 4 orang atau $24 \%$. Secara keseluruhan data setiap indikator ini diperoleh gambaran bahwa ada dua indikator yang memiliki kualitas kurang yaitu menerima tugas, dan terdapat dua indikator yang memiliki kualitas cukup yaitu mempertanggungjawabkan hasil kerja dan berinisiatif sendiri. Temuan penelitian pada siklus II secara keseluruhan kemampuan guru dalam menerapkan layanan informasitelah nampak dalam kegiatan layanan. Hasil tindakan ini dapat meningkatkan kemandirian siswa dalam aktivitas belajar dengan kategori mandiri sebanyak 14 orang atau $82 \%$ dan cukup mandiri sebanyak 3 orang atau $18 \%$. Hasil ini menunjukkan bahwa kategori kemandirian siswa dalam aktivitas belajar yang menonjol adalah mandiri yaitu 14 orang atau $82 \%$.

\section{PENUTUP}

Berdasarkan hasil temuan pada penelitian ini dapat disimpulkan yaitu layanan informasi dapat meningkatkan jumlah siswa yang mandiri adalam aktivitas belajar yaitu 4 orang atau $24 \%$ pada siklus I, meningkat menjadi 14 orang atau $82 \%$ pada siklus II. Hasil ini menunjukkan telah memenuhi indikator kinerja dan hipotesis tindakan yang berbunyi :"jika digunakan layanan informasimaka kemandirian belajar padasiswa kelas IX di SMP Negeri 1 PoneloKepulauankabupaten Gorontalo utara dapat ditingkatkan.

\section{Saran}

Berdasarkan hasil temuan dalam penelitian ini maka disarankan sebagai berikut.

1. Bagi guru yang memilih layanan informasidalam kegiatan pembelajaran perlu bersikap sabar, karena metode ini memerlukan ketekunan dalam penerapannya.

2 Bagi guru disarankan agar dapat menggunakan layanan informasi dalam mengelola pembelajaran di sekolah karena secara prinsipil teknik ini mampu membudayakan dan memberikan kesempatan yang luas kepada siswa untuk belajar secara mandiri sehingga dapat mengalami apa yang diamati dan dirasakan bukan hanya menerapkan konsep semata.

\section{DAFTAR PUSTAKA}




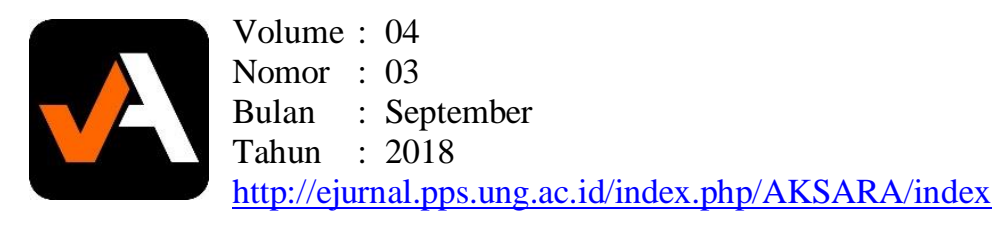

Nurihsan Juntika dan Yusuf Syamsu. 2007. Landasan Bimbingan kelompok. Bandung: Program Pasca Sarjana Universitas Pendidikan Indonesia dan PT Remaja Rosda Karya

Moleong. 2001 Metodologi Penelitian Kualitatif. Cet XIII. Bandung: Remaja Rosdakarya

M. Surya. 1988. Pengantar Bimbingan dan Penyuluhan. Jakarta : UT.

Oemar Hamalik. 2000. Psikologi Belajar dan Mengajar. Bandung: Sinar Baru Algensindo.

Prayitno Erman Amti. 1997. Dasar-dasar Bimbingan kelompok. Jakarta: Depdikbud.

Rustantiningsih.2007.Peran Guru Kelas Dalam Pelaksanaan Bimbingan Bimbingan di sekolah Dasar (Online) Tersedia di http://researchengines.com/rustianti 40708 . htm. (Download, 2 Pebruari 2010)

Sardiman. 2001. Interaksi dan Motivasi Belajar-Mengajar. Jakarta: Raja Grafindo Persada.

Sudirman.2009.Evaluasi Hasil Belajar. Jakarta. Haparan. Masa.

Sudjana. 2010. Pembinaan dan Pengembangan Karir Pengawas Sekolah. (Online). Tersedia di http://akhmadsudrajat.wordpress.com/2008/04/13/pembinaan-danpengembangan-karir-pengawas-sekolah/. . (Download, 2 Pebruari 2010)

Sudradjat Akhmad. 2007. Kesulitan Belajar Siswa dan Bimbingan Belajar (Online) Tersedia di http/www.kes.rtti.,com.press.html

Tim Pengembangan MKDK IKIP Semarang. 1990. Bimbingan kelompok Sekolah. Semarang: IKIP Semarang Press. 